\title{
Peran Norma Deskriptif dan Kepribadian terhadap Perilaku Melawan Arah pada Pengendara Sepeda Motor
}

\author{
Aflah Zakinov Irta, Dewi Maulina, Guritnaningsih A. Santoso \\ Fakultas Psikologi, Universitas Indonesia, Depok, Indonesia \\ e-mail: aflah.zakinov@ui.ac.id
}

\begin{abstract}
This study aims to investigate the role of descriptive norms and personality traits in predicting contraflow riding behavior among motorcyclists. A correlational study was conducted to 156 riders who have the active riding licenses, aged 17 to 51 years old. Participants was given validated scenarios to measure descriptive norm and the contraflow riding behavior, and the Indonesian adapted version of the Big Five self-report to measure extraversion and conscientiousness traits. The results show that descriptive norms have a significant role in predicting contraflow riding behavior. Age has also a significant role in predicting contraflow riding behavior. When the riders perceived that many riders perform contraflow behavior and the younger their age, they are more likely to perform the contraflow riding behavior. Based on this study, the policy makers should make a serious effort in developing the descriptive norms to reduce contraflow riding behavior, especially among young motorcyclists.
\end{abstract}

Keywords: contraflow riding behavior, descriptive norms, extraversion traits, conscientiousness traits, motorcyclists

\begin{abstract}
Abstrak
Penelitian ini bertujuan untuk menguji peran norma deskriptif dan trait kepribadian dalam memprediksi perilaku melawan arah pada pengendara sepeda motor di Jakarta. Penelitian korelasional dilakukan pada 156 pengendara sepeda motor yang memiliki SIM C aktif, berusia 1751 tahun. Partisipan diberikan skenario mengemudi yang sudah divalidasi untuk mengukur norma deskriptif dan perilaku melawan arah, serta skala Big Five self-report yang telah diadaptasi ke dalam Bahasa Indonesia untuk mengukur trait extraversion dan conscientiousness. Hasil penelitian menunjukkan bahwa norma deskripif secara signifikan berperan terhadap perilaku melawan arah. Faktor demografis usia juga merupakan faktor signifikan dalam menentukan perilaku melawan arah. Semakin tinggi pengendara mempersepsi banyak pengendara lain yang berkendara melawan arah dan semakin muda usia mereka, semakin besar kecenderungan pengendara untuk berkendara melawan arah. Implikasi dari hasil temuan ini adalah diperlukan upaya yang serius dari pemangku kebijakan untuk membentuk norma deskriptif yang dapat menurunkan perilaku melawan arah, khususnya pada pengendara sepeda motor usia muda.
\end{abstract}

Kata Kunci: perilaku melawan arah, norma deskriptif, trait extraversion, trait conscientiousness, pengendara sepeda motor

\section{Pendahuluan}

Untuk menunjang aktivitas sehari-hari, penduduk Jakarta dan sekitarnya lebih memilih untuk menggunakan sepeda motor daripada menggunakan mobil pribadi. Jumlah unit kendaraan bermotor pada tahun 2019 di Jakarta mencapai 22.9 juta unit. Berdasarkan data tersebut, 16.95 juta unit adalah kendaraan roda dua (Badan Pusat Statistik, 2019). Sepeda motor menjadi pilihan dalam melakukan mobilitas seharihari karena berkendaraan menggunakan sepeda motor dinilai lebih efektif dalam menembus kemacetan jalan dan menghemat waktu perjalanan (Dandona dkk., 2006; Kamaluddin dkk., 2018). Sejalan dengan tingginya jumlah pengendara sepeda motor di Jakarta dijumpai masalah pelanggaran lalu lintas yang serius. Sebagai contoh, operasi Keselamatan Jaya oleh Kepolisian Metro 
Jaya mendapati pelanggaran sepeda motor yang meningkat hampir 4 kali lipat, yaitu dari 155 pelanggaran di tahun 2018 menjadi 731 pelanggaran di tahun 2019. Di antara berbagai bentuk pelanggaran yang dilakukan oleh pengendara sepeda motor, perilaku melawan arah merupakan jenis pelanggaran yang semakin banyak dilakukan pengendara sepeda motor. Pada tahun 2019, pelanggaran melawan arah yang dilakukan oleh pengendara sepeda motor meningkat sekitar 127 persen dibandingkan tahun sebelumnya (Dananjaya, 2019).

Perilaku melawan arah ditampilkan pengendara dalam bentuk berkendara pada arah yang berlawanan dari lajur yang seharusnya. Perilaku melawan arah merupakan perilaku berkendara yang tidak mematuhi peraturan lalu lintas, sehingga dapat digolongkan sebagai tindakan pelanggaran lalu lintas (Kemel, 2015). Perilaku melawan arah juga digolongkan sebagai perilaku berkendara berisiko (Chang \& Yeh, 2007), yaitu perilaku berkendara yang dapat meningkatkan kemungkinan pengendara dan/ atau orang lain untuk mengalami kecelakaan (Maulina, 2015).

Perilaku berkendaraan melawan arah merupakan perilaku yang tidak saja terjadi di Indonesia, tetapi juga di negara lain seperti di Tiongkok, Jepang, dan beberapa negara di Eropa (Scaramuzza \& Cavegn, 2007; Xing, 2015; Xu dkk., 2014). Dari studi yang telah dilakukan di Eropa ditemukan bahwa faktor demografi yaitu usia pengendara merupakan faktor yang berperan dalam memengaruhi perilaku melawan arah (Scaramuzza \& Cavegn, 2007). Pengendara berusia muda cenderung berkendara melawan arah terutama ketika berada di bawah pengaruh alkohol, sedangkan pada pengendara usia tua perilaku melawan arah lebih berkaitan dengan kemampuan memproses informasi secara visual. Hasil penelitian tersebut menunjukkan bahwa faktor usia sangat erat kaitannya dengan berperannya faktor psikologis. Tampilnya perilaku melawan arah terjadi karena adanya gangguan dalam faktor kognitif yang menyebabkan pengendara tidak dapat mengolah informasi yang terdapat di lingkungan jalan. Mereka tidak dapat membuat keputusan yang tepat dalam menentukan arah dari perjalanannya.

Dalam tinjauan ilmu Psikologi, ditemukan bahwa perilaku berkendara berisiko dipengaruhi oleh banyak faktor seperti faktor kognitif, faktor kepribadian, dan faktor lingkungan sosial. Faktor kognitif yang berpengaruh terhadap perilaku berkendaraan antara lain adalah atensi visual (visual attention) (Anstey dkk., 2012; Hole, 2014) dan persepsi terhadap bahaya (hazard perception) (Castro dkk., 2020; Crundall dkk., 2012; Scialfa dkk., 2012; Young dkk., 2014). Faktor internal lain yang juga berpengaruh terhadap perilaku berkendaraan secara berisiko adalah kepribadian (Nordfjærn dkk., 2012; Taubman-Ben-Ari \& Yehiel, 2012).

Penelitian sebelumnya menemukan bahwa faktor kepribadian seperti rasa cemas, marah, excitement seeking, dan altruisme merupakan prediktor bagi terjadinya perilaku berisiko (Dahlen dkk., 2012; Yang dkk., 2013). Kesimpulan yang berbeda tentang peran kepribadian dikemukakan oleh Thørrisen (2013) dan Ehsani dkk. (2015) bahwa faktor kepribadian yang paling memengaruhi perilaku melanggar lalu lintas adalah trait extraversion dan conscientiousness. Di sisi lain, temuan Santoso dkk. (2011) di daerah Jawa Barat menunjukkan bahwa faktor kepribadian tidak berpengaruh secara signifikan terhadap perilaku berkendaraan berisiko, yaitu mengebut.

Berbagai perbedaan hasil penelitian tentang peran kepribadian terhadap perilaku berkendaraan berisiko menarik untuk diteliti lebih jauh, khususnya tentang peran dari faktor kepribadian terhadap perilaku mengemudi melawan arah. Perbedaan karakteristik antara perilaku berisiko seperti mengebut, yang merupakan jenis 
pelanggaran agresif (aggressive violation) dan melawan arah yang merupakan jenis pelanggaran biasa (ordinary violation) sangat mungkin akan menghasilkan peran faktor kepribadian yang berbeda.

Terkait dengan karakteristik perilaku melawan arah yang dilakukan untuk mendapatkan keuntungan dari segi waktu dan jarak tempuh, maka dalam penelitian ini akan diteliti peran dari faktor trait extraversion dan conscientiousnes. Trait extraversion yang ditandai oleh perilaku mencari stimulasi, aktivitas dan emosi yang positif, membuat individu dengan karakteristik kepribadian extraversion senang mencari cara untuk memecahkan suatu masalah yang dihadapi. Dalam menghadapi situasi jalan memutar yang jauh, individu dengan trait extraversion berpotensi akan memecahkan masalahnya dengan melawan arah. Di sisi lain, karakteristik kepribadian conscientiousness ditandai oleh adanya kebutuhan untuk menaati peraturan (Hogan \& Foster, 2013). Adanya kebutuhan yang dominan untuk memiliki disiplin yang tinggi pada individu dengan trait conscientiousness membuat mereka cenderung mengambil keputusan untuk tidak melakukan perilaku berisiko berkendara seperti melawan arah. Adanya perbedaan peran kepribadian terhadap perilaku berisiko melawan arah pada pengendara sepeda motor ini mendorong peneliti untuk menguji secara empirik peran trait extraversion dan trait conscientiousnes dalam perilaku melawan arah.

Selain faktor internal, berkendara di jalan raya juga dipengaruhi oleh faktor eksternal pengendara, yaitu bagaimana individu mempersepsikan lingkungan sekitar jalan raya. Terdapat norma sosial di jalan raya berupa peraturan lalu lintas yang berlaku, dan juga perilaku pengendara lain yang akan mengarahkan atau membatasi perilaku sosial tertentu (Cialdini \& Trost, 1998). Menurut Cialdini (2012), terdapat dua jenis norma sosial, yaitu norma injunctive dan norma deskriptif. Norma injunctive menggambarkan sejauhmana suatu perilaku akan disetujui oleh individu lain dalam kelompok sosial, sedangkan norma deskriptif mengacu pada persepsi individu tentang apa yang umumnya dilakukan orang lain, terlepas apakah yang mereka lakukan benar atau tidak benar secara moral. Perilaku yang dimunculkan oleh orang lain menjadi dasar informasi bagi individu dalam menentukan suatu perilaku. Sebagai contoh, ketika individu melihat banyak kendaraan diparkir di tempat yang seharusnya dilarang untuk parkir, maka fenomena tersebut dapat menjadi sinyal bahwa memarkir kendaraan di tempat tersebut adalah hal yang wajar. Perspektif sosial yang terbentuk dalam contoh parkir tersebut dipengaruhi oleh persepsi individu tentang apa yang umumnya dilakukan orang lain, terlepas dari apakah mereka benar secara moral. Penelitian sebelumnya di Tiongkok menemukan terdapat hubungan norma deskriptif dan perilaku berkendara berisiko, yang mana penelitian mereka mengaitkan temuannya ini dengan budaya masyarakat Tiongkok dan karakteristik masyarakat yang sensitif terhadap faktor kontekstual (Xu dkk., 2014).

Mengacu pada pentingnya peran budaya dan sensitivitas terhadap pengaruh lingkungan maka penelitian ini ingin menjawab, apakah perilaku melawan arah pada pengendara sepeda motor di Indonesia lebih dapat diprediksi oleh norma sosial, dalam hal ini norma deskriptif, ataukah faktor kepribadian?. Hasil dari penelitian ini diharapkan dapat memberikan kontribusi bagi upaya menurunkan perilaku melawan arah yang berpotensi menyebabkan terjadinya kecelakaan.

\section{Perilaku Melawan Arah}

Perilaku pengendara melawan arah didefinisikan sebagai perilaku berkendaraan dalam lajur yang salah atau berlawanan dari yang seharusnya (Dandona dkk., 2006). Perilaku ini terjadi ketika pengendara, sengaja atau tidak sengaja, berkendaraan pada arah yang berlawanan 
dengan arus lalu lintas (Das dkk., 2018), sehingga merupakan perilaku yang berisiko sebagai penyebab terjadinya kecelakaan lalu lintas (Maulina, 2015). Diantara berbagai jenis kategori perilaku berkendara berisiko, perilaku melawan arah termasuk ke dalam jenis pelanggaran biasa (ordinary violation) (Shinar, 1998).

Penelitian tentang perilaku berkendara melawan arah selama ini umumnya dilakukan dengan pendekatan Theory of Planned Behavior (TPB). Diantara keempat komponen dalam TPB yaitu belief, sikap, norma subyektif, dan persepsi akan kontrol perilaku (perceived behavior control), ditemukan bahwa yang lebih berperan dalam perilaku berkendara melawan arah adalah komponen sikap (Tunnicliff dkk., 2012), dan perceived behavior control (Cristea \& Gheorghiu, 2016). Sikap dan perceived behavior control merupakan dua dari komponen TPB yang dapat menjadi prediktor bagi perilaku melawan arah. Dari temuan tersebut dapat dikatakan bahwa ketika pengendara memiliki sikap positif terhadap perilaku melawan arah, dan mempersepsikan bahwa perilaku melawan arah di bawah kontrol dirinya, maka pengendara akan melakukan perilaku melawan arah.

Penelitian Xu dkk. (2014) di Tiongkok yang mengaitkan perilaku melawan arah dengan budaya dan karakteristik masyarakat Tiongkok yang sensitif terhadap faktor kontekstual berhasil membuktikan bahwa perilaku melawan arah dapat diprediksi berdasarkan norma deskriptif yang dianut individu. Artinya, pengendara sepeda motor akan melakukan perilaku melawan arah ketika ia mempersepsikan bahwa pengendara lain pada umumnya melakukan perilaku melawan arah, terlepas dari apakah mereka benar secara moral.

Pada umumnya penelitian-penelitian sebelumnya menggunakan metode eksperimental dalam menjelaskan pengaruh setiap variabel dengan jenis perilaku berkendara berisiko (Forward, 2009; Scott-
Parker dkk., 2012). Akan tetapi, pada kondisi pandemi COVID-19 dimana sulit untuk melakukan pengukuran dalam situasi terkontrol, maka penelitian ini dilakukan dengan metode non-eksperimental.

\section{Trait Kepribadian}

Penelitian-penelitian sebelumnya telah berhasil menguji hubungan kepribadian dengan perilaku berkendara berisiko (Guo dkk., 2016; Jovanović dkk., 2011a; Lev dkk., 2008; Taubman-Ben-Ari \& Yehiel, 2012). Pengukuran terhadap variabel kepribadian yang sering digunakan dalam berbagai penelitian adalah Five Factor Model (FFM), yang terdiri atas lima subaspek: (1) Extraversion; (2) Openness; (3) Agreeableness; (4) Conscientiousness; dan (5) Neuroticism (Costa \& McCrae, 1995; Soto \& John, 2017). Validitas dan reliabilitas FFM telah teruji sebagai dimensi kepribadian yang mampu mengukur perbedaan individu secara efektif (Jovanović dkk., 2011a; McCrae \& Costa, 2008).

Trait extraversion yang sering dikaitkan dengan kecenderungan mencari sensasi, mendorong individu untuk menampilkan perilaku berkendaraan seperti mengebut, dan perilaku berisiko lainnya. Sementara itu trait conscientiousness ditemukan memiliki hubungan negatif dengan perilaku berkendara berisiko (Lev dkk., 2008). Individu dengan trait conscientiousness yang rendah cenderung menampilkan perilaku berkendaraan berisiko. Mereka menunjukkan ciri kurang pertimbangan, kurangnya kehati-hatian sebelum bertindak, dan membuat rencana di awal dengan cara yang tibatiba. (McCrae \& Costa, 2008). Penelitian lain juga menemukan bahwa trait neuroticism dan agreeableness berhubungan dengan perilaku berkendara berisiko, khususnya perilaku berkendara agresif (Hussain dkk., 2020). Sementara pada penelitian lain ditemukan hubungan trait openness dengan perilaku mengebut (Antoniazzi \& Klein, 2019). Berbagai penelitian tersebut menguji peran sub-aspek 
kepribadian dalam perilaku berkendaraan secara berisiko, khususnya perilaku yang tergolong berkendara secara agresif.

Pada penelitian ini peneliti hanya menggunakan dua sub-aspek, yaitu trait extraversion dan trait conscientiousness dengan alasan kedua trait ini ditemukan memiliki korelasi dengan perilaku berkendaraan berisiko, khususnya jenis ordinary violation (Hussain, 2020). Selain itu, pemilihan kedua sub-aspek kepribadian ini diasumsikan lebih fokus untuk memprediksi perilaku melawan arah mengingat temuan sebelumnya dari penelitian Santoso dkk. (2011) di daerah Jawa Barat, bahwa faktor kepribadian tidak berperan dalam memprediksi perilaku berkendaraan berisiko. Peneliti menduga bahwa trait extraversion secara positif berperan bagi munculnya perilaku melawan arah pada pengendara sepeda motor $(\mathrm{H} 1)$, sedangkan trait conscientiousness berperan secara negatif bagi munculnya perilaku melawan arah pada pengendara sepeda motor untuk berperilaku melawan arah (H2).

\section{Norma Deskriptif}

Penelitian yang dilakukan Santoso dkk. (2011) di daerah pedesaan dan perkotaan Jawa Barat menemukan bahwa risk taking culture yang terdiri dari belief, sikap, norma dan intensi merupakan prediktor yang lebih kuat dibandingkan trait kepribadian bagi terjadinya perilaku berkendara berisiko. Hal ini menunjukkan faktor eksternal seperti norma, sikap atau intensi juga dapat menjelaskan perilaku berkendara. Sejumlah penelitian menemukan bahwa norma sosial merupakan prediktor yang penting terhadap perilaku berkendara berisiko (Carter dkk., 2014; Cialdini \& Trost, 1998; Fruhen \& Flint, 2015).

Norma sosial adalah kebiasaan umum yang menjadi patokan perilaku yang dianggap sebagai tingkah laku yang diterima dalam masyarakat tersebut (Cislaghi \& Heise, 2018). Norma akan berkembang seiring dengan kesepakatan- kesepakatan sosial masyarakatnya. Adanya sebuah norma dalam kelompok bersifat memaksa individu atau kelompok agar berperilaku sesuai dengan aturan yang ada dalam kelompok sosial tersebut. Pada dasarnya, sebuah norma dibentuk agar hubungan diantara manusia dalam masyarakat dapat menciptakan keteraturan sebagaimana yang diharapkan (Bicchieri, 2016).

Cialdini dan Trost (1998) menjelaskan ada dua jenis norma yang relevan dengan pendekatan norma sosial yaitu norma injunctive dan norma deskriptif (descriptive norm). Norma-norma yang bersifat injunctive dan deskriptif seringkali sangat mirip, keduanya mengarahkan individu pada keputusan yang sama untuk berperilaku. Akan tetapi, ahli di bidang psikologi menunjukkan beberapa pengecualian. Norma injunctive mengacu pada perilaku yang benar, yaitu apa yang masyarakat katakan harus dilakukan dalam situasi tertentu (Cialdini \& Trost, 1998). Contohnya hukum mengatur bahwa setiap pengendara harus berhenti ketika lampu merah di persimpangan jalan menyala, atau dilarang melebihi kecepatan maksimum yang ditetapkan di jalan raya. Sementara norma deskriptif mengacu pada persepsi tentang apa yang biasanya dilakukan orang lain (what people actually do) dalam konteks tertentu (Cialdini, 2012). Orangorang mengira bahwa karena orang lain biasa melakukannya, kemungkinan akan muncul perilaku yang efektif dan adaptif terhadap situasi yang bersangkutan (Xu dkk., 2014). Cialdini dan Trost (1998) berpendapat bahwa anggapan seperti itu menawarkan keuntungan informasi dan jalan pintas pada pembuatan keputusan ketika seseorang memilih bagaimana berperilaku dalam situasi tertentu. Dengan hanya memperhatikan apa yang dilakukan sebagian besar orang lain dan meniru tindakan mereka, individu dapat memilih perilaku dengan efisien dan baik. Hal ini dapat dijadikan acuan individu dalam melawan arah di jalan raya. Ketika 
pengendara melihat pengendara lain melakukan perilaku melawan arah, maka individu akan mengikuti perilaku tersebut karena dianggap hal tersebut sudah biasa dilakukan pengendara lain. Hal ini sejalan dengan penelitian yang dilakukan oleh Rivis dan Sheeran (2003) bahwa terdapat hubungan signifikan antara norma deskriptif dengan perilaku berkendara berisiko. Hasil penelitian terdahulu menunjukkan bahwa norma deskriptif memberikan kontribusi unik dalam memprediksi pelanggaran lalu lintas (Forward, 2009). Selain itu, Forward (2009) juga menemukan pengaruh norma deskriptif yang lebih besar dalam situasi yang digambarkan sebagai berisiko. Hal ini menjadi acuan dalam penelitian ini yang mana peneliti menduga norma deskriptif secara signifikan berperan positif dalam memprediksi perilaku melawan arah. Perilaku pengendara lain menjadi informasi bagi individu untuk membuat keputusan dalam perilaku melawan arah. Semakin banyak pengendara lain melakukan pelanggaran melawan arah pada situasi tertentu maka hal tersebut menjadi acuan dalam berperilaku bagi pengendara yang memperoleh informasi tersebut. Norma deskriptif yang diterima berdasarkan proses pengamatan dan pengalaman oleh pengendara dapat meningkatkan kecenderungan pengendara berperilaku yang sama dalam hal ini perilaku melawan arah. Gambar 1 menyajikan alur kerangka berpikir dalam penelitian ini.

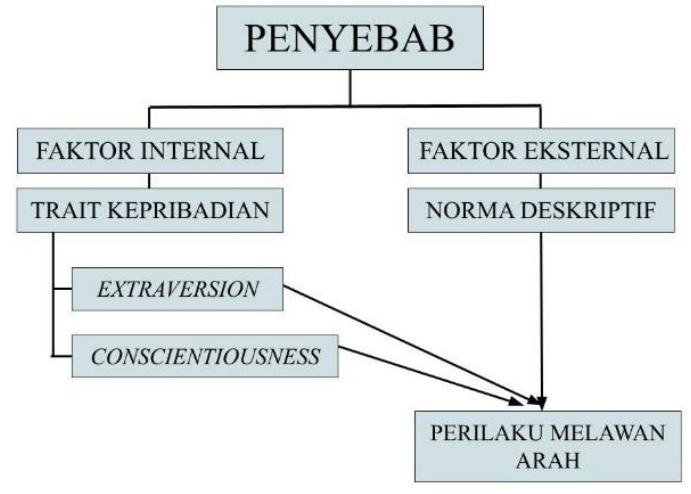

Gambar 1. Kerangka berpikir penelitian

\section{Metode Penelitian}

\section{Tipe dan Desain Penelitian}

Penelitian ini merupakan penelitian korelasional. Terdapat tiga variabel prediktor, yaitu variabel norma deskriptif, trait extraversion dan trait conscientiousness, serta satu variabel outcome yaitu perilaku melawan arah. Perilaku melawan arah diukur dari keputusan pengendara saat diberikan sejumlah skenario berisi situasi-situasi jalan raya yang memungkinkan untuk melakukan melawan arah.

\section{Partisipan}

Partisipan penelitian sebanyak 156 pengendara sepeda motor aktif di Jakarta yang memiliki SIM C. Partisipan terdiri dari 91 laki-laki dan 65 perempuan, yang berada pada rentang usia 17-51 tahun $(M=$ $25.85, S D=9.01)$. Sebanyak $66.03 \%$ partisipan sudah memiliki pengalaman berkendara lebih dari 5 tahun $(M=10.03$, $S D=6.69)$. Partisipan dipilih dengan menggunakan teknik accidental sampling. Rekrutmen partisipan dilakukan secara online melalui media sosial yang disebarkan kepada pengendara sepeda motor yang berdomisili di Jakarta.

\section{Instrumen Penelitian}

\section{Skenario Mengemudi}

Untuk mengukur norma deskriptif dan perilaku melawan arah, peneliti mengembangkan 5 (lima) skenario cerita tertulis tentang situasi-situasi yang berkaitan dengan perilaku melawan arah. Melalui skenario mengemudi, dapat diketahui sejauhmana partisipan mempersepsi norma deskriptif dan memutuskan untuk melawan arah saat diberikan berbagai situasi yang ditemukan di jalan raya. Pengembangan skenario didasarkan pada tinjauan literatur mengenai faktor-faktor eksternal yang secara teoretis memengaruhi perilaku melawan arah dan juga didasarkan pada penelitian sebelumnya yang menggunakan skenario 
mengemudi (Forward, 2009; Xu dkk., 2014).

Pada setiap skenario diberikan dua pertanyaan, terdiri dari satu pertanyaan yang mengukur norma deskriptif dan satu pertanyaan yang mengukur perilaku melawan arah. Pertanyaan yang digunakan untuk mengukur norma deskriptif dan perilaku melawan arah selalu sama pada setiap skenario. Contoh skenario: "Suatu hari Anda sedang berkendara di suatu jalan raya. Di tengah perjalanan, terjadi sebuah kecelakaan lalu lintas yang berada di jalur Anda. Hal tersebut mengakibatkan kondisi kemacetan yang cukup panjang di jalur yang akan anda lalui. Sebaliknya, dari arah jalur yang berlawanan kondisi jalan raya saat itu lancar." Pertanyaan untuk mengukur norma deskriptif adalah "Pada situasi di atas, menurut anda seberapa besar kemungkinan pengendarapengendara sepeda motor akan melawan arah?". Selanjutnya pertanyaan untuk mengukur perilaku melawan arah adalah "Pada situasi di atas, menurut anda seberapa besar kemungkinan anda akan melawan arah?". Terdapat 4 (empat) pilihan jawaban untuk masing-masing pertanyaan, mulai dari 1 (sangat rendah) sampai 4 (sangat tinggi).

Dalam pengembangan skenario berkendaraan, peneliti melakukan uji keterbacaan kepada 10 partisipan dan uji coba kepada 32 partisipan di Jakarta untuk mendapatkan masukan terhadap skenario yang dikembangkan. Berdasarkan hasil uji coba yang dilakukan, peneliti merevisi kembali isi dari skenario mengemudi agar lebih menggambarkan situasi lalu lintas yang memungkinkan pengendara untuk melakukan perilaku melawan arah.

\section{Kuesioner Kepribadian}

Pengukuran terhadap trait extraversion dan trait conscientiousness dilakukan dengan menggunakan kuesioner lapor diri (self report) Big Five versi bahasa Indonesia yang telah terstandarisasi oleh Ramdhani (2012) dengan koefisien reliabilitas yang cukup baik, yaitu
Cronbach alpha $=.73$ untuk trait extraversion dan .78 untuk trait conscientiousness. Kuesioner kepribadian berisi 11 item, yang terdiri dari 6 item yang mengukur trait extraversion (contoh item: "Saya adalah seorang yang bersemangat"), dan 5 item yang mengukur trait conscientiousness (contoh item: "Saya adalah seorang yang melakukan pekerjaan hingga tuntas"). Setiap item terdiri dari lima pilihan jawaban berbentuk skala likert, mulai dari 1 (sangat tidak setuju) sampai 5 (sangat setuju).

\section{Prosedur Penelitian}

Sebelum melakukan pengumpulan data, penelitian ini telah mendapatkan ethical clearance dari Komisi Etik Fakultas Psikologi Universitas Indonesia. Pengumpulan data dilakukan secara online menggunakan Google Form. Pengambilan data dimulai pada bulan Juli sampai dengan Agustus 2020. Pelaksanaan perekrutan partisipan dilakukan dengan cara menyebarkan pengumuman di media sosial dan media elektronik seperti telepon dan pesan singkat. Setelah mendapatkan calon partisipan yang sesuai dengan kriteria yang ditentukan dalam penelitian ini, peneliti mengirimkan link penelitian kepada calon partisipan. Adapun link yang diberikan kepada partisipan merupakan link Google Form yang berisi lembar informasi penelitian, lembar informed consent, dan instrumen penelitian. Peneliti tidak memberikan reward atas keikutsertaan partisipan dalam penelitian ini.

\section{Teknik Analisis Data}

Teknik analisis data dalam penelitian ini menggunakan analisis statistika deskriptif dan juga metode korelasi Pearson untuk mengetahui hubungan antar setiap variabel prediktor dengan variabel perilaku melawan arah. Selain itu dilakukan analisis regresi linear berganda untuk mengetahui seberapa besar peran masingmasing variabel, yaitu norma deskriptif, trait extraversion dan trait conscientiousness, dalam memprediksi 
perilaku melawan arah. Pengolahan data dilakukan dengan program SPSS 26 for windows.

\section{Hasil Penelitian dan Pembahasan}

Berdasarkan tabel 1 dapat disimpulkan bahwa partisipan memiliki norma deskriptif yang tergolong tinggi, artinya rata-rata partisipan mempersepsikan bahwa pengendara lain akan melawan arah pada kelima skenario mengemudi yang diberikan. Pada perilaku melawan arah, hasil penelitian juga menunjukkan bahwa rata-rata partisipan memutuskan untuk melawan arah pada kelima skenario mengemudi yang diberikan. Pada trait kepribadian, dapat dilihat bahwa rata-rata partisipan memiliki trait extraversion dan trait conscientiousness yang tergolong tinggi (mean di atas median skala).
Analisis korelasi menggunakan Pearson correlation dilakukan untuk menguji hubungan antara setiap prediktor, yaitu norma deskriptif, trait extraversion, trait conscientiousness, dan perilaku melawan arah sebagai criterion. Selain ketiga prediktor, peneliti juga memasukkan tiga variabel demografis yang secara teoretis berhubungan dengan perilaku melawan arah, yaitu usia, jenis kelamin, dan pengalaman berkendaraan. Berdasarkan hasil uji korelasi, ditemukan bahwa dari ketiga prediktor, hanya norma deskriptif yang berkorelasi secara positif dan signifikan dengan perilaku melawan $\operatorname{arah}(r=.26, p<.001)$. Selain itu, dari tiga variabel demografis yang ada, hanya usia yang berkorelasi secara negatif dan signifikan dengan perilaku melawan arah $(r$ $=-.23, p<.001$ ) (lihat tabel 2). Berdasarkan hasil ini, pada analisis multiple regression berikutnya peneliti hanya memasukkan

Tabel 1

Gambaran Skor Norma Deskriptif, Trait Extraversion, Trait Conscientiousness dan Perilaku Melawan Arah

\begin{tabular}{lccccc}
\hline \multicolumn{1}{c}{ Variabel } & Median & & & & \\
& Skala & $M$ & $S D$ & Min & Maks \\
\hline Norma Deskriptif & 2.5 & 3.15 & .64 & 1 & 4 \\
Trait Extraversion & 3 & 3.88 & 2.77 & 2.17 & 5 \\
Trait Conscientiousness & 3 & 3.90 & 2.95 & 2.40 & 5 \\
Perilaku Melawan Arah & 2.5 & 3.02 & .48 & 1.50 & 3.50 \\
\hline
\end{tabular}

Tabel 2

Hasil Uji Korelasi antar Variabel

\begin{tabular}{|c|c|c|c|c|c|c|c|c|}
\hline & & 1 & 2 & 3 & 4 & 5 & 6 & 7 \\
\hline 1 & Norma Deskriptif & 1 & & & & & & \\
\hline 2 & Extraversion & -.00 & 1 & & & & & \\
\hline 3 & Conscientiousness & -.06 & $.47 * *$ & 1 & & & & \\
\hline 4 & Usia & -.11 & $.19 *$ & .12 & 1 & & & \\
\hline 5 & Jenis kelamin & .11 & .02 & .01 & -.03 & 1 & & \\
\hline 6 & Pengalaman mengemudi & .01 & -.08 & .02 & .05 & .12 & 1 & \\
\hline 7 & Perilaku Melawan Arah & $.26 * *$ & -.02 & -.13 & $-.23 * *$ & -.06 & .09 & 1 \\
\hline
\end{tabular}

**Signifikan pada $\mathrm{p}=.01$

*Signifikan pada $\mathrm{p}=.05$

Tabel 3

Hasil Uji Multiple Regresion

\begin{tabular}{lccccc}
\hline Model & $B$ & $S E$ & $\beta$ & $t$ & Sig \\
\hline Konstanta & 13.81 & 1.14 & & 12.11 & .00 \\
Norma Deskriptif & .18 & .05 & .24 & 3.16 & .00 \\
Usia & -1.03 & .37 & -.21 & -2.74 & .00 \\
\hline
\end{tabular}


variabel norma deskriptif dan usia sebagai prediktor dari perilaku melawan arah.

Berdasarkan analisis multiple regression, diperoleh hasil bahwa norma deskriptif dan usia terbukti menjelaskan $11.4 \%$ perilaku melawan arah $\left(R^{2}=.114, F\right.$ $=9.84, p<.001)$. Kedua prediktor, yaitu norma deskriptif dan usia, terbukti secara signifikan dapat memprediksi perilaku melawan arah (lihat tabel 3). Norma deskriptif secara positif dan signifikan dapat memprediksi perilaku melawan arah ( $\beta=.24, p<.001)$, artinya semakin tinggi pengendara mempersepsi bahwa pengendara lain banyak yang menampilkan perilaku melawan arah, maka semakin besar kecenderungan pengendara untuk juga menampilkan perilaku melawan arah pada situasi yang diberikan. Selain itu, usia juga ditemukan secara negatif dan signifikan memprediksi perilaku melawan arah $(\beta=.21, p<.001)$, artinya semakin muda usia pengendara maka semakin tinggi kecenderungannya untuk menampilkan perilaku melawan arah. Berdasarkan hasil multiple regression yang diperoleh, dapat disimpulkan persamaan regresi: Melawan $\operatorname{arah}=13.81+.18$ Norma Deskriptif -1.03 Usia. Peningkatan 1 unit norma deskriptif akan diikuti dengan peningkatan kecenderungan untuk melawan arah sebesar .018 unit, sedangkan peningkatan 1 unit usia akan diikuti dengan penurunan kecenderungan untuk melawan arah sebesar 1.03 unit.

Untuk menguji lebih lanjut peran yang signifikan dari usia terhadap perilaku melawan arah, dilakukan analisis perbandingan perilaku melawan arah pada dua kelompok usia yang ada di dalam penelitian ini, yaitu pengendara usia muda (17-26 tahun) dan pengendara usia lebih tua (> 26 tahun). Hasil analisis independent sample t-test menunjukkan bahwa terdapat perbedaan perilaku melawan arah yang signifikan antara kelompok usia 17-26 tahun $(M=15.74, S D=2.23)$ dan usia $>26$ tahun $(M=14.6, S D=2.43), t(154)=3.02$, $p<.05$. Pengendara berusia muda memiliki kecenderungan melakukan perilaku melawan arah yang lebih tinggi dibandingkan pengendara berusia lebih tua.

Penelitian ini ingin menguji apakah perilaku melawan arah pada pengendara sepeda motor di Indonesia lebih dapat diprediksi oleh norma sosial, dalam hal ini norma deskriptif, ataukah faktor kepribadian. Hasil penelitian menunjukkan bahwa dari ketiga prediktor, hanya norma deskriptif yang berperan secara signifikan untuk memprediksi perilaku melawan arah. Di sisi lain, trait extraversion dan trait conscientiousness tidak berperan secara signifikan untuk memprediksi perilaku melawan arah. Selain ketiga prediktor, hasil penelitian menunjukkan bahwa faktor demografis usia juga berperan signifikan dalam memprediksi perilaku melawan arah.

Penelitian ini menunjukkan bagaimana faktor eksternal, yaitu norma deskriptif memiliki peran dalam memprediksi perilaku melawan arah pada pengendara sepeda motor di Jakarta. Hal ini mencerminkan bahwa pada pengendara sepeda di Jakarta berkendara melawan arah didukung oleh adanya pengendara lain yang juga melakukan hal tersebut. Ditemukannya peran signifikan dari norma deskriptif dalam memprediksi perilaku melawan arah pada pengendara sepeda motor ini sejalan dengan temuan dari penelitian $\mathrm{Xu}$ dkk. (2014) bahwa norma deskriptif secara signifikan memengaruhi perilaku berisiko berkendara pada pengendara sepeda motor di China. Ketika pengendara meyakini bahwa di tempat yang ia lalui biasa terjadi perilaku melawan arah yang dilakukan pengendara sepeda motor lain, maka pengendara tersebut cenderung untuk juga melakukan perilaku melawan arah.

Mengacu pada pendapat Cialdini dan Goldstein (2004), bahwa meskipun terdapat intensi untuk berperilaku patuh, pengaruh norma deskriptif bergantung pada situasi. Dengan kata lain, ketika seorang pengendara yang pada awalnya berniat untuk tidak berperilaku melawan arah, namun pada akhirnya melakukan perilaku 
melawan arah disebabkan situasi pada saat itu pengendara tersebut melihat banyak pengendara lain yang melawan arah. Hal inilah yang dapat dikatakan bahwa norma deskriptif memengaruhi keputusan pengendara tersebut untuk melakukan perilaku melawan arah.

Penjelasan lain juga dikemukakan oleh Mawanga dan Ntayi (2010) bahwa kepatuhan terhadap peraturan lalu lintas sangat bergantung pada pengendara lain di jalan raya yang terlibat dalam berkendara berisiko. Norma deskriptif ketidakpatuhan memiliki pengaruh yang jauh lebih besar daripada norma deskriptif kepatuhan dalam masyarakat mana pun (Pillutla, 2011). Hasil ini sejalan dengan penelitian sebelumnya bahwa norma deskriptif secara langsung mampu memprediksi perilaku (Forward, 2008), dimana norma deskriptif meningkatkan varians yang dijelaskan secara substansial ketika situasi dianggap sangat berisiko (Rivis \& Sheeran, 2003). Selain itu, berperannya norma deskriptif dalam memunculkan perilaku melawan arah bisa jadi disebabkan masih lemahnya law enforcement yang dirasakan oleh pengendara (Farrow dkk., 2017).

Dari segi hukum, tata tertib ketentuan berkendara telah diatur oleh UndangUndang nomor 22 tahun 2009 tentang lalu lintas dan angkutan jalan. Akan tetapi, minimnya sosialisasi dan kurangnya konsistensi dalam penegakan aturan lalu lintas menyebabkan pengendara masih berani melakukan perilaku berkendara berisiko dalam bentuk melanggar aturan lalu lintas. Munculnya perilaku berisiko berkendara seperti melawan arah salah satunya didasari oleh keberanian pengendara untuk melanggar, yang disebabkan karena adanya mentalitas bahwa setiap masalah dapat diselesaikan secara "damai" dengan Polisi Lalu Lintas (Polantas). Selain itu, adanya budaya melanggar dan lunturnya budaya malu bahkan bagi sebagian orang menjadi kebanggaan tersendiri apabila dapat mengelabui Polantas atau melanggar rambu rambu lalu lintas (Hendratno, 2009).

Penelitian ini juga menunjukkan bahwa trait kepribadian extraversion dan trait conscientiousness tidak berperan secara signifikan terhadap perilaku melawan arah. Hasil penelitian ini berbeda dengan penelitian sebelumnya yang menemukan bahwa trait extraversion dan trait conscientiousness secara signifikan berkorelasi dengan perilaku berkendara berisiko (Hussain dkk., 2020; Jovanovic dkk., 2011b). Penelitian sebelumnya juga menemukan bahwa trait conscientiousness berhubungan positif dengan perilaku berhati-hati terhadap keselamatan berkendara (Skvrsky dkk., 2017). Di sisi lain, hasil penelitian ini sejalan dengan penelitian sebelumnya yang menemukan bahwa trait extraversion dan trait conscientiousness tidak memprediksi variabel perilaku berisiko berkendara (Alavi dkk., 2017; Tao dkk., 2017; Ucho dkk., 2016).

Sifat kepribadian dari trait extraversion yang digambarkan sebagai sifat supel, menyukai kesenangan, mudah bergaul dan lincah (Wilmot dkk., 2019), mungkin menjadikan perilaku melawan arah sebagai kesenangannya (Akinniyi dkk., 2019). Namun penelitian Lu dkk. (2017) menjelaskan bentuk pencarian kesenangan yang dirasakan tiap individu berbeda berdasarkan faktor demografi dan budaya. Hal tersebut bisa saja menjelaskan mengapa dalam penelitian ini tidak ditemukan hubungan antara trait extraversion dan perilaku melawan arah. Perilaku melawan arah yang ditampilkan belum tentu merupakan suatu bentuk pencarian kesenangan bagi pengendara yang memiliki trait extraversion di Jakarta sehingga perilaku melawan arah yang dimunculkan tidak sepenuhnya didorong oleh kepribadian pengendara tersebut. Hasil penelitian ini juga sejalan dengan penelitian yang dilakukan Akbari dkk. (2019) yang mana trait conscientiousness tidak memiliki pengaruh terhadap perilaku 
berisiko berkendara. Pengendara yang dominan dengan trait conscientiousness dalam berkendara lebih dipengaruhi oleh norma hukum yang berlaku, nilai kepatuhan pada dirinya, sehingga cenderung tidak menimbulkan aksi negatif dalam berkendara seperti mengebut dan menerobos lampu merah (Linkov dkk., 2019). Hal ini memperkuat temuan dalam penelitian ini bahwa trait conscientiousness tidak memengaruhi perilaku melawan arah pada pengendara sepeda motor di Jakarta.

Dalam menjelaskan hasil penelitian yang menunjukkan tidak terdapat hubungan signifikan antara trait extraversion dan trait conscientiousness dengan perilaku melawan arah, perlu juga dipahami bahwa kesimpulan tentang kegunaan Big Five Personality Model dalam perilaku berkendara dinilai masih prematur. Pada penelitian sebelumnya, instrumen yang digunakan untuk menilai trait kepribadian belum sepenuhnya konsisten untuk menjelaskan hubungannya dengan perilaku berisiko berkendara (Dahlen \& White, 2006). Selain itu, banyak penelitian sebelumnya memiliki partisipan dengan rentang usia yang jauh lebih luas (Barahmand dkk., 2016; Wang dkk., 2019). Beberapa penelitian sebelumnya secara eksklusif memasukkan varibel trait extraversion dengan menggunakan partisipan laki-laki saja (Hasanzadeh dkk., 2017; Wu dkk., 2020), sehingga sebagian besar penelitian tersebut tidak mengontrol faktor-faktor seperti jenis kelamin, status sosial ekonomi atau jarak tempuh.

Pada penelitian ini, tidak ditemukannya peran signifikan dari faktor kepribadian bisa disebakan karena tidak dimasukkannya faktor-faktor lain yang bisa jadi secara eksklusif berhubungan dengan trait kepribadian. Perlu diingat bahwa penelitian-penelitian sebelumnya lebih banyak meneliti hubungan antara trait kepribadian dengan perilaku berkendara berisiko seperti berkendara agresif (Anitei dkk., 2014; Jovanovic dkk., 2011b; Shen dkk., 2018), mengebut (Greaves \& Ellison
2011; Zicat dkk., 2018) dan juga perilaku menerobos lampu merah (Lucidi, 2019). Berdasarkan literature review yang dilakukan, peneliti tidak banyak menemukan penelitian yang menjelaskan hubungan antara trait kepribadian dengan perilaku melawan arah. Dengan demikian, penelitian tambahan diperlukan untuk menentukan sejauhmana ditemukan hasil penelitian yang konsisten terkait hubungan antara trait kepribadian dan perilaku melawan arah pada pengendara sepeda motor.

Pada dasarnya hasil penelitian ini menemukan bahwa perilaku melawan arah lebih dimotivasi oleh norma sosial dibanding trait kepribadian, bukanlah suatu yang mengherankan, mengingat masyarakat Indonesia dikenal sebagai masyarakat yang memiliki budaya kolektif. Budaya kolektif erat hubungannya dengan kecenderungan untuk berperilaku mirip dengan orang lain. Sebuah eksperimen yang dilakukan Hashimoto (2019) dapat memberikan gambaran bagaimana budaya kolektif suatu masyarakat memengaruhi keputusan individu. Dalam salah satu eksperimennya, mereka membagi peserta dari budaya individualis yaitu Amerika dan Jepang yang menganut budaya kolektif untuk memilih sebuah pena. Sebagian pena memiliki warna yang sama, dengan beberapa pilihan warna berbeda. Sebagian besar peserta Amerika memilih pena berwarna yang lebih langka, sedangkan peserta dari Jepang sebaliknya lebih cenderung memilih pena berwarna yang paling umum, meskipun mereka lebih suka pena yang lebih langka. Hasil ini menunjukkan bagaimana budaya memengaruhi keputusan individu dalam berperilaku. Individu yang berada dalam budaya kolektif lebih cenderung berperilaku menyesuaikan dengan apa yang biasanya dilakukan oleh individu lain. Apabila dikaitkan dengan perilaku melawan arah, pengendara menampilkan perilaku tersebut karena meniru perilaku yang banyak dilakukan oleh pengendara lain dan menganggap bahwa perilaku melawan arah 
merupakan sesuatu yang biasa untuk dilakukan.

Budaya kolektif sendiri juga dikatakan lebih kuat kaitannya dengan konformitas dibanding masyarakat yang memiliki budaya individualis (Oh, 2013). Konformitas sendiri diartikan setiap perubahan perilaku yang disebabkan oleh individu atau kelompok lain, individu berperilaku dalam beberapa cara karena pengaruh dari orang lain (Cherry, 2020). Jika dikaitkan dengan perilaku pengendara sepeda motor di Indonesia, khususnya di Jakarta, keputusan untuk berperilaku melawan arah lebih disebabkan karena perilaku serupa yang dilakukan oleh pengendara lain. Mereka merasa nyaman melakukan suatu perilaku yang umum dilakukan oleh orang lain. Hal ini menunjukkan bahwa pengaruh budaya menjadi salah satu alasan individu dalam mengambil suatu keputusan meskipun pada awalnya seorang pengendara yang ingin mematuhi aturan dengan tidak melawan arah lalu lintas akan dapat mengubah keputusannya ketika melihat banyak pengendara lain yang melakukan perilaku melawan arah. Adanya peran yang besar dari lingkungan terhadap diri pengendara menjelaskan mengapa dalam penelitian ini ditemukan bahwa norma deskriptif lebih berperan dalam memprediksi perilaku melawan arah daripada trait kepribadian yang dimiliki masing-masing pengendara.

Hasil yang menarik dari penelitian ini adalah ditemukannya peran variabel demografis usia dalam memprediksi perilaku melawan arah. Hal ini sejalan dengan penelitian sebelumnya yang menyatakan bahwa usia adalah salah satu variabel demografis yang signifikan dan berperan penting dalam memunculkan perilaku berkendaraan berisiko pada pengendara sepeda motor, salah satunya dalam bentuk perilaku melawan arah (Chiou dkk., 2020; Zamani Sani dkk., 2020). Hasil penelitian ini juga memperkuat hasil penelitian sebelumnya bahwa pengendara berusia muda lebih cenderung menampilkan perilaku berkendara berisiko dibandingkan pengendara usia tua (Vahedi dkk., 2018). Pengendara berusia muda menganggap perilaku berkendara berisiko seperti melanggar aturan lalu lintas bukan merupakan sesuatu yang penting dibandingkan pengendara yang lebih tua. Sikap negatif pengendara yang lebih muda terhadap perilaku berisiko berkendara di jalan raya kemungkinan besar terkait dengan ketidakpedulian mereka terhadap pihak berwenang, khususnya kepada otoritas polisi lalu lintas (Oulmokhtar dkk., 2011). Lebih jauh lagi, peraturan lalu lintas cenderung menimbulkan respons negatif karena dianggap membatasi kebutuhan pengendara yang lebih muda untuk mencari sensasi (Zhang dkk., 2019).

Penelitian ini tidak luput dari beberapa keterbatasan. Pertama, pengukuran dalam penelitian ini seluruhnya dikumpulkan dalam bentuk self-report, sehingga terdapat kemungkinan bagi partisipan untuk memberikan respon yang sesuai dengan harapan lingkungan atau memiliki risiko bias social desirability, khususnya untuk kuesioner yang terkait dengan masalah perilaku melawan arah (Stanojevic dkk., 2018). Meskipun penulis mencoba untuk membatasi bias social desirability dengan meyakinkan partisipan bahwa jawaban mereka bersifat anonim, namun temuan dari penelitian ini tetap harus dilakukan dengan hati-hati karena pengukuran perilaku dan norma deskriptif juga dapat meningkatkan kemungkinan common method bias yang menggambarkan kesalahan pengukuran yang disebabkan sosiabilitas responden yang ingin memberikan jawaban yang positif (Chang dkk., 2020). Untuk mengatasi bias ini, penelitian di masa mendatang disarankan untuk mengintegrasikan pengukuran selfreport dengan metode lain seperti observasi lapangan dan simulasi berkendara. Kedua, pengukuran perilaku melawan arah dalam penelitian ini dilakukan secara umum, artinya dalam penelitian ini tidak melihat 
secara spesifik berbagai bentuk perilaku melawan arah, seperti yang terdapat pada beberapa penelitian sebelumnya yang menggunakan variabel opposite manouver rider (Lattarulo dkk., 2017) yaitu perilaku melawan arah pada jalur yang sudah ditentukan (Otte dkk., 2015) dan variabel seperti contraflow riding (Burkin, 2019).

Ketiga, penelitian ini merupakan penelitian korelasional, yaitu desain penelitian yang tidak melibatkan perbandingan antara kelompok kontrol dan eksperimen sehingga kesimpulan mengenai hubungan sebab akibat menjadi terbatas. Penelitian terdahulu menggunakan metode eksperimen dengan membagi partisipan ke dalam kelompok kontrol dan kelompok perlakuan (Xu dkk., 2014). Pada penelitian tersebut, norma deskriptif dimanipulasi pada kelompok yang menerima perlakuan dengan diberikan kuisioner yang menginformasikan bahwa pelanggaran lalu lintas biasa terjadi sementara kelompok kontrol tidak diberikan informasi tersebut. Untuk dapat menyimpulkan adanya hubungan sebab akibat, sebaiknya penelitian selanjutnya menggunakan metode eksperimental sehingga pengaruh norma deskriptif terhadap perilaku melawan arah dapat lebih jelas digambarkan hubungannya.

Berdasarkan hasil penelitian ini, diharapkan penelitian ini dapat dijadikan acuan dan tambahan referensi bagi pihak yang berwenang dalam penegakan hukum di bidang lalu lintas dalam memahami perilaku pengendara sepeda motor. Secara khusus, diperlukan adanya upaya oleh pihak berwenang untuk meningkatkan law enforcement terkait perilaku pelanggaran lalu lintas yang dilakukan oleh pengendara sepeda motor.

\section{Simpulan}

Penelitian ini menunjukkan bahwa norma deskriptif merupakan faktor eksternal yang berperan dalam memprediksi perilaku melawan arah pada pengendara sepeda motor di Jakarta.
Semakin tinggi keyakinan pengendara bahwa pengendara lain di lingkungannya banyak yang melakukan perilaku melawan arah, maka pengendara akan semakin terdorong untuk menampilkan perilaku melawan arah. Di sisi lain, trait extraversion dan trait conscientiousness tidak berperan secara signifikan terhadap perilaku melawan arah. Faktor internal pengemudi yang ditemukan berperan secara signifikan terhadap perilaku melawan arah adalah usia sebagai salah satu faktor demografis pengendara.

\section{Daftar Pustaka}

Akbari, M., Kamran, B. L., Heydari, S. T., Motevalian, S. A., Tabrizi, R., AsadiShekari, Z., \& Sullman, M. J. (2019). Meta-analysis of the correlation between personality characteristics and risky driving behaviors. Journal of injury and violence research, 11(2), 107.

https://dx.doi.org/10.5249\%2Fjivr.v11i 2.1172

Akinniyi, R. J., Akinnawo, E. O., Akpunne, B. C., \& Oyeleke, J. T. (2019). The predictive influence of demographic and personality traits on risky driving behaviour among traffic offenders in Osun State, Nigeria. Current Journal of Applied Science and Technology, 1-12. https://doi.org/10.9734/CJAST/2019/v $35 i 430192$

Aniței, M. I. H. A. I., Chraif, M. I. H. A. E. L. A., Burtaverde, V., \& Mihaila, T. (2014). The big five personality factors in the prediction of aggressive driving behavior among Romanian youngsters. International Journal of Traffic and Transportation Psychology, 2(1), 7-20.

Anstey, K. J., Horswill, M. S., Wood, J. M., \& Hatherly, C. (2012). The role of cognitive and visual abilities as predictors in the multifactorial model of driving safety. Accident Analysis \& 
Prevention, 45, 766-774. https://doi.org/10.1016/j.aap.2011.10.0 06

Antoniazzi, D., \& Klein, R. (2019). Risky riders: A comparison of personality theories on motorcyclist riding behaviour. Transportation Research Part F: Traffic Psychology and Behaviour, 62, 33-44. https://doi.org/10.1016/j.trf.2018.12.00 8

Alavi, S. S., Mohammadi, M. R., Soori, H., \& Ghanizadeh, M. (2017). The cognitive and psychological factors (Personality, driving behavior, and mental illnesses) as predictors in traffic violations. Iranian Journal of Psychiatry, 12(2), 78.

Badan Pusat Statistik (2019). Perkembangan jumlah kendaraan bermotor menurut jenis, 1949-2017. Badan Pusat Statistik. https://www. bps. go. id/linkTableDinamis.

Barahmand, U., Nabidoost, A., \& Daryadel, S. J. (2016). The association of personality dimensions, perceived stress and emotion regulation to driving anger among taxi drivers in Iran. Jurnal Sains Kesihatan Malaysia (Malaysian Journal of Health Sciences), 14(2), 129-140. http://dx.doi.org./10.17576/JSKM2016-1402-15

Bicchieri, C. (2016). Norms in the wild: How to diagnose, measure, and change social norms. Oxford University Press.

Burkin, L. P. (2019). Against the grain: Safety analysis and design guidance for shared contraflow bike streets (Doctoral dissertation unpublished). Tufts University Department of Urban and Environmental Policy.

Carter, P. M., Bingham, C. R., Zakrajsek, J. S., Shope, J. T., \& Sayer, T. B. (2014). Social norms and risk perception: Predictors of distracted driving behavior among novice adolescent drivers. Journal of Adolescent Health, 54(5), S32-S41. https://doi.org/10.1016/j.jadohealth.20 14.01.008

Castro, C., Muela, I., Doncel, P., \& GarciaFernandez, P. (2020). Hazard perception and prediction test for walking, riding a bike and driving a car: "Understanding of the global traffic situation". PLoS one, 15(10), e0238605.

https://doi.org/10.1371/journal.pone.02 38605

Chang, H. L., \& Yeh, T. H. (2007). Motorcyclist accident involvement by age, gender, and risky behaviors in Taipei, Taiwan. Transportation Research Part F: Traffic Psychology and Behaviour, 10(2), 109-122. https://doi.org/10.1016/j.trf.2006.08.00 1

Chang S. J., van Witteloostuijn A., \& Eden L. (2020). Common method variance in international business research. Dalam Eden L., Nielsen B., Verbeke A. (eds) Research methods in international business. JIBS Special Collections. Palgrave Macmillan, Cham. https://doi.org/10.1007/978-3030-22113-3_20

Cherry, K. (2020). How does conformity influence behavior. VeryWell Mind.

Chiou, Y. C., Fu, C., \& Ke, C. Y. (2020). Modelling two-vehicle crash severity by generalized estimating equations. Accident Analysis \& Prevention, 148, 105841.

https://doi.org/10.1016/j.aap.2020.105 841

Cialdini, R. B., \& Goldstein, N. J. (2004). Social influence: Compliance and conformity. Annu. Rev. Psychol., 55, 591-621.

https://doi.org/10.1146/annurev.psych. 55.090902 .142015

Cialdini, R., \& Trost, M. R. (1998). Social influence: Social norms, conformity, and compliance. Dalam D. T. Gilbert, S. T. Fiske, \& G. Lindzey (Eds.). The handbook of social psychology. Boston: 
https://doi.org/10.1146/annurev.psych. 55.090902 .142015

Cialdini, R. B. (2012). The focus theory of normative conduct. Dalam P. A. M. Van Lange, A. W. Kruglanski, \& E. T. Higgins (Eds.), Handbook of theories of social psychology (hal. 295-312). Sage Publications Ltd. https://doi.org/10.4135/978144624922 2.n41

Cislaghi, B., \& Heise, L. (2018). Theory and practice of social norms interventions: Eight common pitfalls. Global Health 14, 83. https://doi.org/10.1186/s12992-0180398-x

Costa, P. T., \& McCrae, R. R. (2006). Age changes in personality and their origins: Comment on Roberts, Walton, and Viechtbauer. Psychological Bulletin . Psychol. Bull. 132(1), 26-28. https://doi.org/10.1037/00332909.132.1.26

Cristea, M., \& Gheorghiu, A. (2016). Attitude, perceived behavioral control, and intention to adopt risky behaviors. Transportation Research Part F: Traffic Psychology and Behaviour, 43, 157-165.

https://doi.org/10.1016/j.trf.2016.10.00 4

Crundall, D., Chapman, P., Trawley, S., Collins, L., Van Loon, E., Andrews, B., \& Underwood, G. (2012). Some hazards are more attractive than others: Drivers of varying experience respond differently to different types of hazard. Accident Analysis \& Prevention, 45, 600-609. https://doi.org/10.1016/j.aap.2011.09.0 49

Dahlen, E. R., Edwards, B. D., Tubré, T., Zyphur, M. J., \& Warren, C. R. (2012). Taking a look behind the wheel: An investigation into the personality predictors of aggressive driving. Accident Analysis and Prevention, 45, $1-9$. https://doi.org/10.1016/j.aap.2011.11.0 12

Dahlen, E. R., \& White, R. P. (2006). The big five factors, sensation seeking, and driving anger in the prediction of unsafe driving. Personality and individual differences, 41(5), 903-915. http://dx.doi.org/10.1016/j.paid.2006.0 3.016

Dananjaya, D. (2019). Ingat lagi sanksi melawan arah: Bisa kena denda Rp.500.000. Otomotif Kompas. https://otomotif.kompas.com/read/2019 /10/30/124200715/ingat-lagi-sanksimelawan-arah-bisa-kena-denda-rp500.000

Dandona, R., Kumar, G. A., Raj, T. S., \& Dandona, L. (2006). Patterns of road traffic injuries in a vulnerable population in Hyderabad, India. Injury prevention, 12(3), 183-188. https://doi.org/10.1136/ip.2005.010728

Das, S., Dutta, A., Jalayer, M., Bibeka, A., $\& \mathrm{Wu}, \mathrm{L}$. (2018). Factors influencing the patterns of wrong-way driving crashes on freeway exit ramps and median crossovers: Exploration using 'Eclat' association rules to promote safety. International Journal of Transportation Science and Technology, 7(2), 114-123. https://doi.org/10.1016/j.ijtst.2018.02.0 01

Ehsani, J. P., Li, K., Simons-Morton, B. G., Tree-McGrath, C. F., Perlus, J. G., O'Brien, F., \& Klauer, S. G. (2015). Conscientious personality and young drivers' crash risk. Journal of safety research, 54, 83.e29-87. https://doi.org/10.1016/j.jsr.2015.06.01 5

Farrow, K., Grolleau, G., \& Ibanez, L. (2017). Social norms and proenvironmental behavior: A review of the evidence. Ecological Economics, 140 , 1-13. https://doi.org/10.1016/j.ecolecon.2017 .04 .017 
Forward, S. E. (2009). The theory of planned behaviour: The role of descriptive norms and past behaviour in the prediction of drivers' intentions to violate. Transportation Research Part F: Traffic Psychology and Behaviour 12(3), 198-207. https://doi.org/10.1016/j.trf.2008.12.00 2

Fruhen, L. S., \& Flin, R. (2015). Car driver attitudes, perceptions of social norms and aggressive driving behaviour towards cyclists. Accident Analysis \& Prevention, 83, 162-170. https://doi.org/10.1016/j.aap.2015.07.0 03

Guo, M., Wei, W., Liao, G., \& Chu, F. (2016). The impact of personality on driving safety among Chinese highspeed railway drivers. Accident Analysis \& Prevention, 92, 9-14. https://doi.org/10.1016/j.aap.2016.03.0 14

Greaves, S. P., \& Ellison, A. B. (2011). Personality, risk aversion and speeding: An empirical investigation. Accident Analysis \& Prevention, 43(5), 1828-1836. https://doi.org/10.1016/j.aap.2011.04.0 18

Hasanzadeh, S., Dao, B., Esmaeili, B., \& Dodd, M. D. (2019). Role of personality in construction safety: investigating the relationships between personality, attentional failure, and hazard identification under fall-hazard conditions. Journal of construction engineering and management, 145(9), 04019052.

https://doi.org/10.1061/(ASCE)CO.194 3-7862.0001673

Hashimoto, H. (2019). Interdependence in a Japanese cultural context: Distinguishing between preferences and expectations. The Japanese Journal of Experimental Social Psychology, 59(1), 51-55. https://doi.org/10.2130/jjesp.1815
Hendratno, E. T. (2009). Masalah transportasi kota dilihat dengan pendekatan hukum, sosial dan budaya. Mimbar Hukum-Fakultas Hukum Universitas Gadjah Mada, 21(3), 494506. https://doi.org/10.22146/jmh.16275

Hogan, J., \& Foster, J. (2013). Multifaceted personality predictors of workplace safety performance: More than conscientiousness. Human Performance, 26(1), 20-43. https://doi.org/10.1080/08959285.2012 .736899

Hole, G. J. (2014). The psychology of driving. Psychology Press.

Hussain, B., Sato, H., Miwa, T., \& Morikawa, T. (2020). Influence of personality traits on aberrant driving behaviors: A comparison of Japanese, Chinese, and Vietnamese drivers. Journal of safety research, 75, 178188.

https://doi.org/10.1016/j.jsr.2020.09.01 1

John, O. P., \& Srivastava, S. (1999). The big-five trait taxonomy: History, measurement, and theoretical perspectives, 2, 102-138. University of California.

Jovanović, D., Lipovac, K., Stanojević, P., \& Stanojević, D. (2011a). The effects of personality traits on driving-related anger and aggressive behaviour in traffic among Serbian drivers. Transportation Research Part F: Traffic Psychology and Behaviour, 14(1), 43-53. https://doi.org/10.1016/j.trf.2010.09.00 5

Jovanović, D., Stanojević, P., \& Stanojević, D. (2011b). Motives for, and attitudes about, driving-related anger and aggressive driving. Social Behavior and Personality, 39(6), 755764. https://doi.org/10.2224/sbp.2011.39.6.7 55 
Kamaluddin, N. A., Andersen, C. S., Larsen, M. K., Meltofte, K. R., \& Várhelyi, A. (2018). Self-reporting traffic crashes-a systematic literature review. European transport research review, 10(2), 1-18. https://doi.org/10.1186/s12544-0180301-0

Kemel, E. (2015). Wrong-way driving crashes on French divided roads. Accident Analysis and Prevention, 75, 69-76.

https://doi.org/10.1016/j.aap.2014.11.0 02

Lattarulo, R., Marcano, M., \& Pérez, J. (2017). Overtaking maneuver for automated driving using virtual environments. In International Conference on Computer Aided Systems Theory, 10672, 446-453. Springer, Cham. https://doi.org/10.1007/978-3-31974727-9_54

Lev, D., Hershkovitz, E., \& Yechiam, E. (2008). Decision making and personality in traffic offenders: A study of Israeli drivers. Accident Analysis \& Prevention, 40(1), 223230.

https://doi.org/10.1016/j.aap.2007.05 .009

Linkov, V., Zaoral, A., Řezáč, P., \& Pai, C. W. (2019). Personality and professional drivers' driving behavior. Transportation research part F: traffic psychology and behaviour, 60, 105-110. https://doi.org/10.1016/j.trf.2018.10. 017

Lu, A. C. C., Chi, C. G. Q., \& Lu, C. Y. R. (2017). Sensation seeking, message sensation value, and destinations: A cross-cultural comparison. Journal of Hospitality \& Tourism Research, 41(3), 357-383. https://doi.org/10.1177/109634801455 0872

Lucidi, F., Girelli, L., Chirico, A., Alivernini, F., Cozzolino, M., Violani,
C., \& Mallia, L. (2019). Personality traits and attitudes toward traffic safety predict risky behavior across young, adult, and older drivers. Front Psychology. 10, 536. https://doi.org/10.3389/fpsyg.2019.005 36

Mawanga, F. F., \& Ntayi, J. M. (2010). Social norms and compliance with road traffic rules in urban areas: Initial impressions of drivers in Kampala, Uganda. Journal of Transport and Supply Chain Management, 4(1), 138150.

https://doi.org/10.4102/jtscm.v4i1.16

Maulina, D. (2015). The influence of riskyriding script, distance perception, and risk perception on risky-riding behavior among motorcysclists in prorisk and anti-risk situations (Pengaruh script berkendaraan berisiko, persepsi jarak, dan persepsi risiko terhadap perilaku berkendaraan berisiko pada pengendara sepeda motor dalam situasi pro-risk dan anti-risk) (Disertasi tidak diterbitkan). Universitas Indonesia.

McCrae, R. R., \& Costa, P. T., Jr. (2008). The five-factor theory of personality. Dalam O. P. John, R. W. Robins, \& L. A. Pervin (Eds.), Handbook of personality: Theory and research (hal. 159-181). The Guilford Press.

Nordfjærn, T., Jørgensen, S. H., \& Rundmo, T. (2012). Safety attitudes, behaviour, anxiety and perceived control among professional and nonprofessional drivers. Journal of Risk Research, 15(8), 875-896. https://doi.org/10.1080/13669877.2012 .670132

Oh, S. H. (2013). Do collectivists conform more than individualists? Crosscultural differences in compliance and internalization. Social Behavior and Personality: an international journal, 4l(6), 981-994. http://dx.doi.org/10.2224/sbp.2013.41. 6.981 
Otte, D., Facius, T., \& Wiese, B. (2015). Accident characteristics and influence parameters of severe motorcycle accidents in Germany. SAE Technical Paper, 2015-01-1466. https://doi.org/10.4271/2015-01-1466.

Oulmokhtar, D., Krauth-Gruber, S., Alexopoulos, T., \& DrozdaSenkowska, E. (2011). Police officers' stereotype content and its evolution over two decades: From "neither nice nor able" to "still not nice but able". Revue internationale de psychologie sociale, 24(3), 87-100.

Pillutla, M. M. (2011). When good people do wrong: Morality, social identity, and ethical behavior. Dalam D. De Cremer, R. van Dick, \& J. K. Murnighan (Eds.), Social psychology and organizations (hal. 18). Routledge.

Ramdhani, N. (2012). Adaptasi bahasa dan budaya inventori big five. Jurnal Psikologi, $\quad 39(2), \quad$ 189-205. https://doi.org/10.22146/jpsi.6986

Rivis, A., \& Sheeran, P. (2003). Descriptive norms as an additional predictor in the theory of planned behaviour: A meta-analysis. Current Psychology, 22(3), 218-233. https://doi.org/10.1007/s12144-0031018-2

Santoso, G. A., Maulina, D., \& Suharso, P. L. (2011). Pengaruh karakteristik kepribadian, risk taking culture, dan persepsi risiko terhadap perilaku mengebut (speeding) pada pengemudi sepeda motor di daerah perkotaan dan pedesaan. Laporan Penelitian. DRPM UI.

Scaramuzza, G., \& Cavegn, M. (2007). 'Wrong-way drivers: Extentinterventions'. The European Transport Conference, Leeuwenhorst Conference Centre, The Netherlands

Scialfa, C. T., Borkenhagen, D., Lyon, J., Deschênes, M., Horswill, M., \& Wetton, M. (2012). The effects of driving experience on responses to a static hazard perception test. Accident
Analysis and Prevention, 45, 547-553. https://doi.org/10.1016/j.aap.2011.09.0 05

Scott-Parker, B., Watson, B., King, M. J., \& Hyde, M. K. (2012). Confirmatory factor analysis of the behaviour of young novice drivers scale (BYNDS). Accident Analysis and Prevention 49, 385-391.

https://doi.org/10.1016/j.aap.2012.02.0 21

Shen, B., Ge, Y., Qu, W., Sun, X., \& Zhang, K. (2018). The different effects of personality on prosocial and aggressive driving behaviour in a Chinese sample. Transportation research part $F$ : traffic psychology and behaviour, 56, 268-279. https://doi.org/10.1016/j.trf.2018.04.01 9

Shinar, D. (1998). Aggressive driving: The contribution of the drivers and the situation. Transportation Research Part F: traffic psychology and behaviour, 1(2), 137-160. https://doi.org/10.1016/S13698478(99)00002-9

Skvirsky, V., Ben-Ari, O. T., Greenbury, T. J., \& Prato, C. G. (2017). Contributors to young drivers' driving styles-A comparison between Israel and Queensland. Accident Analysis \& Prevention, 109, 47-54. https://doi.org/10.1016/j.aap.2017.08.0 31

Soto, C. J., \& John, O. P. (2017). Short and extra-short forms of the big five inventory-2: The BFI-2-S and BFI-2XS. Journal of Research in Personality, 68, 69-81. https://doi.org/10.1016/j.jrp.2017.02.00 4

Stanojević, P., Lajunen, T., Jovanović, D., Sârbescu, P., \& Kostadinov, S. (2018). The driver behaviour questionnaire in south-east europe countries: Bulgaria, Romania and Serbia. Transportation research part $F$ : traffic psychology and behaviour,

53 ,

24-33. 
https://doi.org/10.1016/j.trf.2017.12.01 1

Taubman-Ben-Ari, O., \& Yehiel, D. (2012). Driving styles and their associations with personality and motivation. Accident Analysis and Prevention, 45, 416-422. https://doi.org/10.1016/j.aap.2011.08.0 07.

Tao, D., Zhang, R., \& Qu, X. (2017). The role of personality traits and driving experience in self-reported risky driving behaviors and accident risk among Chinese drivers. Accident Analysis \& Prevention, 99, 228-235. https://doi.org/10.1016/j.aap.2016.12.0 09

Thørrisen, M. M. (2013). Personality and driving behavior. The role of extraversion and neuroticism in drivers' behavior toward bicyclists (Master's thesis unpublished). University of Oslo.

Tunnicliff, D. J., Watson, B. C., White, K. M., Hyde, M. K., Schonfeld, C. C., \& Wishart, D. E. (2012). Understanding the factors influencing safe and unsafe motorcycle rider intention. Accident Analysis and Prevention, 49, 133- 141. https://doi.org/10.1016/j.aap.2011.03.0 12

Ucho, A., Terwase, J. M., \& Ucho, A. A. (2016). Influence of big five personality traits and locus of control on road safety rules compliance among motorcycle riders in north-central Nigeria. Asia Pacific Journal of Education, Arts and Sciences, 3(1), 19.

Vahedi, J., Shariat Mohaymany, A., Tabibi, Z., \& Mehdizadeh, M. (2018). Aberrant driving behaviour, risk involvement, and their related factors among taxi drivers. International journal of environmental research and public health, 15(8), 1626. https://doi.org/10.3390/ijerph15081626

Wang, X., Huang, K., \& Yang, L. (2019). Effects of socio-demographic, personality and mental health factors on traffic violations in Chinese bus drivers. Psychology, health \& medicine, 24(7), 890-900. https://doi.org/10.1080/13548506.2019 .1567928

Wilmot, M. P., Wanberg, C. R., Kammeyer-Mueller, J. D., \& Ones, D. S. (2019). Extraversion advantages at work: A quantitative review and synthesis of the meta-analytic evidence. Journal of Applied Psychology, 104(12), 1447-1470. https://doi.org/10.1037/apl0000415

Xing, J. (2015). Characteristics of wrongway driving on motorways in Japan. IET Intelligent Transport Systems, 9(1), 3-11. https://doi.org/10.1049/ietits.2014.0017

Xu, Y., Li, Y., \& Jiang, L. (2014). The effects of situational factors and impulsiveness on drivers' intentions to violate traffic rules: Difference of driving experience. Accident Analysis and Prevention, 62, 54-62. https://doi.org/10.1016/j.aap.2013.09.0 14

Yang, J., Du, F., Qu, W., Gong, Z., \& Sun, X. (2013). Effects of personality on risky driving behavior and accident involvement for Chinese drivers. Traffic Injury Prevention, 14(6), 565571.

https://doi.org/10.1080/15389588.2012 .748903

Young, A. H., Chapman, P., \& Crundall, D. (2014). Producing a commentary slows concurrent hazard perception responses. Journal of experimental psychology: applied, 20(3), 285. https://doi.org/10.1037/xap0000016

Zamani Sani, S. H., Fathirezaie, Z., \& Sadeghi-Bazargani, H. (2020). Investigation of the relationship between motor vehicle driver violations, visual search, attention deficit hyperactivity disorder, and age of drivers. Advances in Cognitive 
Science, 22(1),

$1-12$.

http://dx.doi.org/10.30699/icss.22.1.1

Zhang, X., Qu, X., Tao, D., \& Xue, H. (2019). The association between sensation seeking and driving outcomes: A systematic review and meta-analysis. Accident Analysis \& Prevention, 123, 222-234. https://doi.org/10.1016/j.aap.2018.11.0 23

Zicat, E., Bennett, J. M., Chekaluk, E., \& Batchelor, J. (2018). Cognitive function and young drivers: The relationship between driving, attitudes, personality and cognition. Transportation research part F: traffic psychology and behaviour, 55, 341352

https://doi.org/10.1016/j.trf.2018.03.01 3 